lay down again ; that was about 12 o'clock. Asked him if his daughter should not be sent for. Wrote a letter to request his niece to come, as he said she could best be spared. He gave witness's danghter half-a-crown to buy two boxes of Morison's pills with, as she returned from the post-office, and while she was gone witness took him up a cup of tea, which he drank, and she again left him. On her daughter's return with a packet of pills, and 3d., in change, she went to him again, and found him with a little stool close by his bedside on his knees upon the stool, as if at prayer, and his head on the bed, lying on his arms; called in a neighbour, and lifted him on the bed, but he was quite dead. He had vomited a quart of greenish matter or fluid, and lay in it; this was about 7 o'clock in the evening. He was a penurious man, and was under no proper medical treatment. He was in the habit of taking Morison's pills : had heard him speak very highly of them. On Monday, he told her he had taken 10 pills, and that he ought to have taken 20. He was much emaciated, and suffered great pain. He was possessed of a little property, and witness was one of his tenants. He told witness that he thought his illness came on from painting a tenant's house last week,

Mr. R. Davison, surgeon, said that he had examined the body of the deceased, and had found no marks of external violence ; upon opening the body, he found the stomach and bowels in a highly inflamed state, with a quantity of thin yellow fluid, and upon exarining the fluid, he found it to contain a certain quantity of aloes, but principally gamboge, which are two medicines of a very violent and drastic nature, and such as, in his opinion, were highly injurious to a person of the emaciated and delicate constitution of the deceased. Witness was also of opinion that the inflamed state of the bowels and stomach was the cause of his death, but whether the medicine would cause the inflammation he could not say, but such medicine would cause and increase inflammation, and was an improper medicine to give him. Upon examination of the pills, they were found to contain gamboge and aloes, which were the same ingredients which he detected in the stomach. The powder contains, amongst other ingredients, cream of tartar, or tartaric acid, and cinnamun, but he could not state precisely without making an analysis of the contents. The examination was nade in the presence of Mr. Marriott, surgeon, and assistant.

Verdict-" That the deceased died from natural causes, but that his death was accelerated by taking Morison's pills."

We are informed that the deceased was so prepossessed in favour of Morison's pills, that during his life he may be said to have taken peck of them.

\section{FREQUENT INOCULATION OF SMALL-POX IN ENGLAND.}

\section{To the Editor of The IAANCET.}

SIR :-In a late Number of The LANCET is published an account of the revaccinations in the Prussian army during the year 1837, by which the power of the vaccine disease as a preventative of small-pox is forcibly demonstrated, and its utility to that kingdom clearly manifested. On reading this state. ment $I$ was naturally struck with the great contrast which at present exists between this nation and Prussia, as regards the appreciation and benefits of vaccination. I think, Sir, that the Prussian physicians would scarcely believe it if they were told that whilst they were enjoying, so eminently, in conjunction with the greater part of the world, the blessiugs resulting from the discovery of vaccination, in England, the land of its origin, thousands annually perish from small-pox, and that in almost every parish vaccination is rejected by a large proportion of the inhabitants, and inoculation practised with impunity by any one who chooses to adopt it.

With all due deference I would venture to call the attention of the different medical associations established in the kingdom to the subject, as being one of deep professional as well as national interest.

To say nothing of its existence elsewhere, the small-pox has been prevalent in the southern counties for upwards of two years, and is now raging, with unusual severity, in many places. During last winter a case occurred in this place, and, notwithstanding every endeavour was made to prevent contagion, matter was taken from the patient by a woman who sat up with her through the night, and in the course of a few days many hundreds were inoculated; in due time the disease became general, and many lives were lost. I mention this as an example of the present state of vaccination in the country. In the above manner is the small-pox continued from town to town and parish to parish. The law, as it now stands, affords no protection either to the medical man or the public, and unless some change takes place it is but too evident that the time is fast approaching when, as in days of old, the small-pox will become again a deforming and fearful scourge among us.

Secondary cases after inoculation have become very common, which seems to indicate that our constitutions are becoming more susceptible of the disease.

The policy of a legislative interference to prevent inoculation altogether, becomes now a question, but surely it is to be deeply regretted that the propagation of so fearful a disease as the small-pox should be open to the discrimination of the ignoran and 
prejudiced among the lower classes. The old law, whieh rendered it peral to expose a child having the small-pox, is perfectly useless, and has no power to prevent inoculation, which is the great evil. I am, Sir, your obedient servant,

\section{J. D. JFFFer, Surgeon.}

Sidmouth, Augr. 21, 1838.

\section{SMALL-POX AND VACCINATION.}

\section{To the Fditor of The Lacicer.}

Sir:-Although I firmly believe that vac. cination does prevent, in certain constitutions, the occurrence of small-pox, still I cannot think it by any means a certain preventive which so many sanguine "Jennerians" have held it out to be. I have lately attended four patients labouring under variola, and as there are some circumstances connected with them which, in my opinion will weaken the faith placed in vaccination (and thereby spur us on to further reseaches, into the subject), I have taken the liberty of transmitting thein for publication in your valuable Journal. I have the honour to be, Sir, your constant subscriber,

\section{A. B. Mabuock.}

B0, Judd-street, Bronswick-square.

On the 1st of June I was called to attend the eldest child of Mi's. W-n, 39, Hadlow street, who complained of fever, together with the other symptoms which usually precede variola. As soon as the eruption appeared the mother took the other three children, by my advice, to the Small-pox Hospital, and had them vaccinated; there were four insertions made in each of the arms of the children. In the course of seveu days a large vesicle became fully developed in the place of each insertion, surrounded by a well-marked e?loriscence; in fact, these cases presented all the symptoms which the racciue virus is capable of producing. The small-pox, however, made its formidable appearance just at the very time when the vaccine pustules had arrived at their full height; the variolons disease and the raccine vesicle extended simultaneously, and this, too, in the full rigour of their respective powers, thus claiming, in defiance of each other, it peculiar right to settle in the system.

P.S. Since writing the above my attention has been directed to a similar case forwarded to you by my friend, Mr. Wilkin, of Walton, to whom I was formerly assistant. I am glad to find that my opinion is supported by so able a practitioner.

\section{OBITUARY.}

Wre regret to have to announce the death, at Paris, of Dr. Alexander Thomson, son of Professor A. T. Thomson, of University College. Dr. A. Thomson was an ardent cultivator of medical science, and deroted with enthusiasm to the canse of medieal reform.

\section{BOOK RECEIVED.}

Chemistry of Organic Bodies, - Vege. tables. By Thomas Thomson, MI.D., Sic. Baillière, London, sro., pp. 1076.

\section{TO CORRESPONDENTS.}

TuE correspondent at Jersey, one in N. B., and others in England, who have sent questions relative to their means of remedy against debtors under the new Act for abolishing arrest, will find their inquiries fully answered in an edition of the Act which has been published, with a preface and notes, in a cheap form, by $\mathrm{Mr}$. Wells, the barrister, and might easily be obtained through any bookseller. 'The replies would occupy too much space for insertion in our columns. 'The Act does not extend to Jersey, nor to Scutland or Ireland, but parties residing in those countries of course can exercise the powers of the new Act against debtors in Eingland.

The communication of $\mathrm{Dr}$. Hancoch in our next Viumber.

The Report in unr last Number renders it unuecessary for us to publish the remarks of IIr. Evans. With regard to the statements in which the name of Sir Philip Crampton has been used, we have been assured "that the account contained an exact report of what occurred on the occasion, and that the words and observations ascribed to Sir Philip were given rerbatim, without the slightest alteration, as they came from the lips of that gentleman, in the preseuce of several witnesses, who may not be surprised to hear that Sir Philip is a disbeliever of ' animal magnetisun,' but who might be astonished to hear him allege that he did not make the remarks which he is reported to have uttered."

An Old Subscriber. Yes, he is legally qualified. The diploma is not necessary to render the appointment legal.

The pamphlet on Medical Reform was received, and shall be noticed.

Communications have been received from Projessor Dieffenbach, Berlin; Mr. P. Ben. net Lucas, Mir. Wood, Mr. Chinnock, NIr. Birch, Mr. Hare, Wr. Morrah, and fustitin et Miserecordia. 